\title{
A Taxonomy to Understand Scaling of Innovation by African Enterprises
}

\section{Chris Armstrong}

Research Associate, LINK Centre, University of the Witwatersrand (Wits), Johannesburg; Senior Research Associate, Centre for Law, Technology and Society (CLTS), University of Ottawa; and Researcher, Open African Innovation Research (Open AIR)

(iD https://orcid.org/0000-0002-3478-2579

\section{Jeremy de Beer}

Professor, Faculty of Law, University of Ottawa; Co-Founding Director, Open African Innovation Research (Open AIR); Senior Fellow, Centre for International Governance Innovation (CIGI), Waterloo, Canada; Senior Research Associate, IP Unit, University of Cape Town

iD https://orcid.org/0000-0001-9753-3708

\begin{abstract}
Grounded in empirical research findings and key statements in the literature, this article proposes a four-part taxonomy for mapping African knowledge-based enterprises' efforts to achieve scale. The taxonomy, adapted from the framework proposed by Uvin et al. (2000), is comprised of scaling by expanding coverage; by broadening activities; by changing behaviour; and by building sustainability. The article sets out the framework and provides examples of the four scaling dimensions from empirical research conducted in Egypt, Tunisia, Morocco, Ghana, Nigeria, Ethiopia, Uganda, Kenya, Botswana, and South Africa.
\end{abstract}

\section{Keywords}

scaling, innovation, enterprises, Africa, definitions, taxonomies, scaling up, scaling out, scaling down, scaling in, expanding coverage, broadening activities, behaviour change, sustainability

\section{Acknowledgements}

The empirical research findings outlined in this article are derived from case studies managed and funded by the Open African Innovation Research partnership (Open AIR), with the individual studies guided and overseen by Open AIR Steering Committee members (in alphabetical order): Jeremy de Beer (University of Ottawa), Erika Kraemer-Mbula (University of Johannesburg), Caroline Ncube (University of Cape Town), Chidi Oguamanam (University of Ottawa), Nagla Rizk (The American University in Cairo), Isaac Rutenberg (Strathmore University, Nairobi) and Tobias Schonwetter (University of Cape Town). Research management was provided by Nan Warner (University of Cape Town) and Victoria Schorr (University of Ottawa). The literature review findings in this article emerged from the research assistance 
provided by (in alphabetical order) Gaëlle Groux, Sileshi Hirko, Chijioke Okorie, Chukwuka Okwuosa, Nickolas Robelek, Sarah Thuswaldner, S. Nicole Tumaine and Uchenna Ugwu.

Open AIR is a partnership between the University of Cape Town, the University of Johannesburg, The American University in Cairo, Kenya's Strathmore University, the Nigerian Institute of Advanced Legal Studies, and the University of Ottawa. Funding support for the case studies and literature review discussed in this article was provided by the Social Sciences and Humanities Research Council (SSHRC) of Canada and the International Development Research Centre (IDRC). The views expressed in this work are those of the authors and do not necessarily represent those of the research funders.

DOI: $\underline{\text { https://doi.org/10.23962/10539/31370 }}$

\section{Recommended citation}

Armstrong, C., \& De Beer, J. (2021). A taxonomy to understand scaling of innovation by African enterprises. The African Journal of Information and Communication (AJIC), 27,1-22. https://doi.org/10.23962/10539/31370

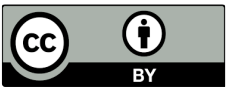

This article is licensed under a Creative Commons Attribution 4.0 International (CC BY 4.0) licence: https://creativecommons.org/licenses/by/4.0

\section{Introduction}

There is general agreement in African innovation ecosystems-among policymakers, private-sector players, non-profit entities, researchers, academics, and others- that a successful innovation is one that can "scale" or "scale up". However, not enough attention is given to what scaling actually entails, and what it looks like when it is happening, on the ground in African innovation settings. For example, there is a marked difference between the process of taking a new commercial business to market and the process of increasing the effectiveness of a health information campaign. Yet both involve, at least to some extent, scaling of an innovation. The aim of this article is to set out a taxonomy of scaling that captures the realities of not only the two examples just cited, but also of the myriad other ways in which African innovators are seeking, and achieving scale.

We and our colleagues in the Open African Innovation Research partnership (Open AIR) have undertaken numerous case studies looking at the practices and perspectives of collaborative innovators in African settings-including these innovators' approaches to achieving scale and their views on the forms that scaling can take. We 
have also worked to conduct an extensive review of literature on scaling. In this article, we present a taxonomy of four scaling dimensions-expanding coverage; broadening activities; changing behaviour; and building sustainability — that revealed themselves during the course of the exploration of the literature and of the case study findings. ${ }^{1}$

\section{Literature relevant to innovation-scaling in African settings}

\section{Definitions}

Efforts to define scaling are prominent in the literature in the fields of health, education, agriculture, information and communication technology (ICT), social innovation, business and management, microfinance, and development work by non-governmental organisations (NGOs). In the health sector, scaling-up is a frequently used term, particularly in examinations of global health matters (see Johns \& Torres, 2005; Simmons \& Shiffman, 2007; Simmons et al., 2007; Uvin, 1995). According to Simmons et al. (2007), scaling-up can be defined as an "effort to magnify the impact of health service innovations successfully tested in pilot or experimental projects so as to benefit more people and to foster policy and programme development on a lasting basis" (Simmons \& Shiffman, 2007, p. 1).

In the context of education and its role in development, DeJong and UNESCO (2014, p. 21) define scaling-up as "the process [...] of expanding the scale of activities with the ultimate objective of increasing the numbers of people reached and the impact on the problem at hand". In the literature relating to scaling-up in agriculture, one of the most influential definitions is that published in 2000 by the International Institute of Rural Reconstruction (IIRR). The IIRR definition states that to scale up is to bring "more quality benefits to more people over a wider geographical area more quickly, more equitably and more lastingly" (IIRR, 2000, p. iv). Wigboldus et al. (2016, p. 2), writing in the context of agricultural research and innovation, find that scaling is typically cast in terms of "the extent to which outputs and outcomes in the form of novel technologies and practices can lead to wider benefits".

In their volume focused on scaling of impact from social innovations grounded in scientific research, McLean and Gargani (2019) offer this definition: "Scaling impact is a coordinated effort to achieve a collection of impacts at optimal scale that occurs if it is both morally justified and warranted by the dynamic evaluation of evidence" (2019, p. 9). In the literature on NGOs' programme delivery and sustainability, Uvin's (1995) approach-focused on scaling's quantitative, functional, political and organizational dimensions-is widely cited.

1 For a more detailed account of the literature review, the development of the taxonomy, and the mapping of empirical research findings against the taxonomy, see Open AIR (2020). 
In the field of information and communication technology for development (ICT4D), Foster and Heeks (2013) focus on scaling in the context of ICT innovation at the base of the pyramid (BoP). They remind us that "[w]e know little about the dynamics of scaling, about the particular impact of the BoP context, or about the changing relation between scaling strategy, the process of scaling, and the nature of innovation within that context" $(2013$, p. 4).

\section{Scaling up, out, down, in}

Uvin et al. (2000) and others propose that scaling is typically both "up" and "out",i.e., both vertical and horizontal. But there are nuances in how researchers delineate these dimensions. Vertical integration (scaling-up), according to Uvin et al. (2000,p. 1411), occurs "when organizations add upstream or downstream activities that complement their original program, seeking to better control the environment and ensure sustainability of impact." Meanwhile, horizontal integration (scaling-out), for Uvin et al. (2000, p. 1411), "consists of an expansion in the number and diversity of the activities undertaken [and] is often done upon request by beneficiaries or donors". Duggan et al. (2013), drawing on CGIAR (1999), define scaling-up as "institutional in nature" and involving "other sectors/stakeholder groups in the process of expansion", and scaling-out as "geographical spread to cover more people and communities [that] involves expansion within the same sector or stakeholder group across geographical boundaries" (2013, p. 159).

For Gündel et al. (2001), vertical scaling (scaling-up) involves "institutional” expansion to other sectors or stakeholders, e.g., "from grassroots organisations to policymakers, donors, development institutions and international investors", while horizontal scaling [scaling-out] is "geographical" expansion "to more people and communities within the same sector or stakeholder group" (2001, p. 1). According to Wigboldus et al. (2016), scaling-up is "something similar to increasing (e.g., in terms of numbers, speed, size)", while scaling-out "often relates to expanding, such as geographically spreading the use of a particular technology" (2016, p. 2). Critchley (1999, drawing on Scarborough et al. (1997)), conceives of scaling-up as "expanding", and scaling-out as "influencing other organisations" (1999, p. 270). In our analysis, while it is important to recognise that both vertical and horizontal dimensions are typically present in scaling, it is less important to strictly distinguish between the elements that are headed up and those that are headed out-because typically elements of both will be present, intermingled.

Duggan et al. (2013), drawing on CGIAR (1999), propose the additional notions of "scaling down", which they characterise as "increasing participation by decentralization of accountabilities and responsibilities" and "scaling in", which they say is "values and culture based" (2013, p. 159). 


\section{Principles, processes, stages}

McLean and Gargani (2019) argue that in order to ensure that scaling occurs in a manner that serves the "public good", it must be guided by observance of four principles: justification, optimal scale, coordination, and dynamic evaluation. DeJong and UNESCO (2014) propose the following key principles: scaling-up within existing systems and policies; local ownership and leadership; grounding in evaluated pilot programmes; and ensuring sustainability and adaptability of the project beyond its funding timeline.

Writing in the agricultural context, Wambugu et al. (2001, p. 489) propose a community-based approach to scaling-up that requires: building "partnerships with a range of stakeholders"; ensuring appropriateness of practice, and farmers' interest in it; assisting local communities "to be effective in mobilising local and external resources"; and ensuring "effective participation of farmer groups and other stakeholders in testing, disseminating, monitoring, and evaluating the practice".

Earl et al. (2001), in setting out their "outcome mapping" approach to monitoring and evaluating of development projects, point to the fact that "[w] hen large-scale change — or impact-manifests itself, it is often the product of a confluence of events over which no single agency has control or can realistically claim full credit" (Earl et al., 2001, p. xi). Accordingly, Earl et al. (2001) advise that development initiatives seeking sustainability focus on contributing, along with other actors, to "outcomes". They define outcomes as "changes in the behaviour, relationships, activities, or actions of the people, groups, and organizations with whom a program works"(Earl et al., 2001, p. 1). They also speak of "boundary partners", which they define as the "individuals, groups, and organizations with whom the program interacts directly and with whom the program anticipates opportunities for influence" (Earl et al., 2001, p. 1).

In a similar vein, Duggan et al. (2013, p. 159), in speaking of the importance to scaling of involving "other stakeholders/sectors", write that this kind of scaling is "institutional in nature [and] involves other sectors/stakeholder groups in the process of expansion-from the level of grassroots organizations to policymakers, donors, development institutions and investors at international levels". Duggan et al. (2013, p. 153) also point to the transformative power of the internet as "a significant enabler of scale".

Additionally, Duggan et al. (2013) draw a link between the scaling dynamics of the internet and the internet's role in supporting development of "communities of practice" (2013, p. 154). The concept of communities of practice can be found deployed in literature across a wide range of disciplines, as evidenced by the Koliba and Gadja (2009) review of community-of-practice literature. A key developer of the community-of-practice concept is Wenger, and Wenger et al. (2002) write that "[c] 
ommunities of practice are groups of people who share a concern, a set of problems, or a passion about a topic, and who deepen their knowledge and expertise in this area by interacting on an ongoing basis" (2002, p. 4). Communities of practice have a strong scaling dynamic, as their vitality depends to a large extent on their growth through drawing in additional participants, via online and/or offline outreach and interactions.

Foster and Heeks (2013) see scaling-up as "a four-stage process of exploratory, incremental then aggressive growth, followed by (attempted) standardisation" (2013, p. 2). They also set out the importance of using a BoP approach in the process of scaling-up, and of using scaling-up processes that are locally owned. Gündelet al.(2001) conceive of scaling-up of innovations as a two-pronged process, comprising identification of appropriate strategies for acceleration, and providing a framework to guide the acceleration. Gillespie (2004) emphasises the importance of local ownership, local support, and sustainability in successful scaling-up, finding that there is a "need for donors and supporters [...], including governments, to think of the process beyond the project, and of transformation or transition rather than exit" (2004, p. ii, italics in original).

\section{The proposed taxonomy}

As explained in the introduction to this article, the taxonomy proposed in this article is grounded in both the relevant literature and empirical research findings. Table 1 below lists the empirical case studies, conducted in 10 African countries, whose findings inform the taxonomy.

Table 1: Case studies with findings on African scaling modalities

\begin{tabular}{|c|c|c|c|}
\hline $\begin{array}{l}\text { Study } \\
\text { coun- } \\
\text { try(ies) }\end{array}$ & Study & Researchers/authors & $\begin{array}{l}\text { Publi- } \\
\text { cation } \\
\text { year(s) }\end{array}$ \\
\hline Egypt & $\begin{array}{l}\text { Power relations, innovation, scaling, and } \\
\text { knowledge governance at three Egyptian } \\
\text { tech hubs: An initial exploration }\end{array}$ & $\begin{array}{c}\text { ElHoussamy, Wehe- } \\
\text { ba, Rizk }\end{array}$ & 2020 \\
\hline $\begin{array}{l}\text { Egypt, } \\
\text { Tunisia, } \\
\text { Morocco }\end{array}$ & The maker movement across North Africa & ElHoussamy, Rizk & $\begin{array}{l}2018, \\
2020\end{array}$ \\
\hline Ghana & $\begin{array}{l}\text { Skills development, knowledge and inno- } \\
\text { vation at Suame Magazine, Kumasi }\end{array}$ & Adu-Gyamfi, Adjei & 2018 \\
\hline
\end{tabular}




\begin{tabular}{|c|c|c|c|}
\hline \multirow[t]{2}{*}{ Nigeria } & $\begin{array}{l}\text { Determinants of innovation capability in } \\
\text { informal settings: The case of Nigeria's } \\
\text { clustered ICT microenterprises }\end{array}$ & $\begin{array}{l}\text { Jegede, O.O., Jegede, } \\
\text { O. E. }\end{array}$ & 2018 \\
\hline & $\begin{array}{c}\text { The Nollywood phenomenon: Innovation, } \\
\text { openness and technical opportunism in } \\
\text { the modeling of successful African entre- } \\
\text { preneurship }\end{array}$ & Oguamanam & $\begin{array}{l}2018 \\
2020\end{array}$ \\
\hline Ethiopia & $\begin{array}{l}\text { Determinants of innovation in Ethiopian } \\
\text { informal-sector micro and small enterpris- } \\
\text { es (MSEs) }\end{array}$ & Belete & $\begin{array}{l}2018 a, \\
2018 b\end{array}$ \\
\hline Uganda & $\begin{array}{l}\text { ICTs in agricultural production and } \\
\text { potential deployment in operationalising } \\
\text { geographical indications in Uganda }\end{array}$ & Dagne, Oguamanam & 2018 \\
\hline Kenya & $\begin{array}{c}\text { Modes of innovation and enterprise } \\
\text { development by Nairobi's mobile tech } \\
\text { startups }\end{array}$ & $\begin{array}{l}\text { Nzomo, Mwangi, } \\
\text { Matu-Mureithi, } \\
\text { Muchiri, Rutenberg }\end{array}$ & $\begin{array}{l}2020 a, \\
2020 b\end{array}$ \\
\hline Botswana & $\begin{array}{l}\text { MSMEs and open collaborative innova- } \\
\text { tion in Botswana }\end{array}$ & Ama, Okurut & 2018 \\
\hline $\begin{array}{l}\text { South Af- } \\
\text { rica, Kenya }\end{array}$ & $\begin{array}{l}\text { 3D printing: Enabler of social entrepre- } \\
\text { neurship in Africa? The roles of FabLabs } \\
\text { and low-cost 3D printers }\end{array}$ & $\begin{array}{l}\text { Schonwetter, Van } \\
\text { Wiele }\end{array}$ & $\begin{array}{l}2018 \\
2020\end{array}$ \\
\hline \multirow{7}{*}{$\begin{array}{l}\text { South } \\
\text { Africa }\end{array}$} & $\begin{array}{l}\text { Innovation entanglement at three South } \\
\text { African tech hubs }\end{array}$ & Abrahams & 2020 \\
\hline & $\begin{array}{l}\text { Empowering rural women crafters } \\
\text { in KwaZulu-Natal: The dynamics of } \\
\text { intellectual property, traditional cultural } \\
\text { expressions, innovation and social entre- } \\
\text { preneurship }\end{array}$ & Oriakhogba & 2020 \\
\hline & $\begin{array}{c}\text { Complexities of social innovation and } \\
\text { social entrepreneurship by two Indigenous } \\
\text { organisations in rural South Africa }\end{array}$ & Rutert, Traynor & 2019 \\
\hline & $\begin{array}{l}\text { Institutionalisation and informal innova- } \\
\text { tion in South African maker communities }\end{array}$ & $\begin{array}{l}\text { Armstrong, De Beer. } \\
\text { Kraemer-Mbula, } \\
\text { Ellis }\end{array}$ & 2018 \\
\hline & A scan of South Africa's maker movement & $\begin{array}{l}\text { De Beer, Armstrong, } \\
\text { Ellis } \\
\text { Kraemer-Mbula }\end{array}$ & 2017 \\
\hline & $\begin{array}{l}\text { The maker movement in Gauteng Prov- } \\
\text { ince, South Africa }\end{array}$ & $\begin{array}{l}\text { Kraemer-Mbula, } \\
\text { Armstrong }\end{array}$ & 2017 \\
\hline & A data commons for food security & $\begin{array}{l}\text { Baarbé, Blom, De } \\
\text { Beer }\end{array}$ & $\begin{array}{l}2017 \\
2019\end{array}$ \\
\hline
\end{tabular}


In reflecting on the findings from the above-listed studies, and on the statements in the literature as also cited above, we concluded that the aforementioned Uvin et al. (2000) four-part taxonomy of scaling-(1) expanding coverage and size, (2) increasing activities, (3) broadening indirect impact, and (4) enhancing organisational sustainability - is the framework in the existing literature that comes closest to describing the scaling modalities found on the ground in African innovation settings. Accordingly, the taxonomy we propose (see Figure 1) is grounded in the Uvin et al. (2000) taxonomy, with small modifications.

\section{Figure 1: Proposed scaling taxonomy (adapted from Uvin et al. (2000))}

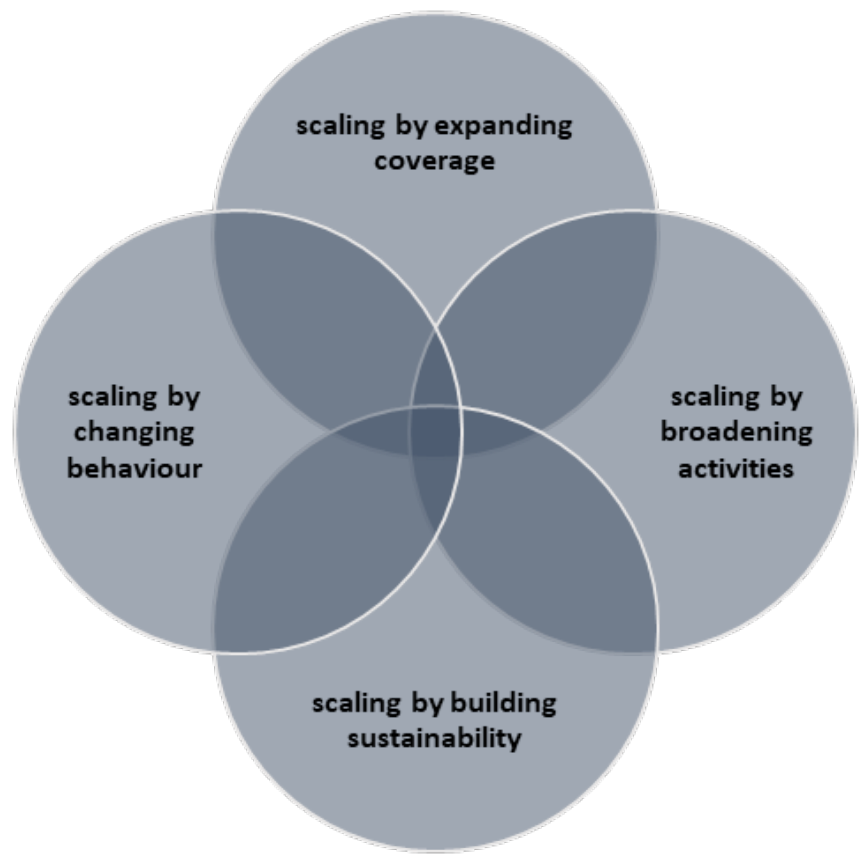

Tables 2 through 5 below provide some of the key statements in the literature that inform the four parts of the taxonomy, including statements from Uvin et al. (2000).

Table 2: Scaling by expanding coverage

\begin{tabular}{|c|c|}
\hline $\begin{array}{l}\text { vin et al. }(2000, \\
\text { p. } 1411)\end{array}$ & $\begin{array}{c}\text { "cover a larger number of beneficiaries, typically in a larger geograph- } \\
\text { ical area" }\end{array}$ \\
\hline $\begin{array}{l}\text { IIRR ( } 2000, \mathrm{p} . \\
\text { iv) }\end{array}$ & $\begin{array}{l}\text { bring "more quality benefits to more people over a wider geographical } \\
\text { area more quickly, more equitably and more lastingly" }\end{array}$ \\
\hline $\begin{array}{r}\text { DeJong a } \\
\text { ESCO } \\
\text { p. } 2\end{array}$ & $\begin{array}{r}\text { "[expand] the scale of activitie } \\
\text { ing the numbers of people re } \\
\text { hand" }\end{array}$ \\
\hline $\begin{array}{r}\text { Günd } \\
(200\end{array}$ & $\begin{array}{l}\text { "geographical spread to more people and communities within the } \\
\text { same sector or stakeholder group" }\end{array}$ \\
\hline
\end{tabular}


Table 3: Scaling by broadening activities

\begin{tabular}{|c|c|}
\hline $\begin{array}{c}\text { Uvin et al. } \\
(2000, \text { p. } 1411)\end{array}$ & "expansion in the number and diversity of the activities undertaken" \\
\hline $\begin{array}{c}\text { Uvin et al. } \\
(2000, \text { p. } 1417)\end{array}$ & $\begin{array}{c}\text { "multiplication and mainstreaming through spinning off organisations, } \\
\text { letting go of innovations, creating alternative knowledge, and influenc- } \\
\text { ing other social actors" }\end{array}$ \\
\hline $\begin{array}{c}\text { Duggan et al. } \\
(2013, \text { p. } 156)\end{array}$ & $\begin{array}{c}\text { "adapting an innovation successful in some local setting to effective } \\
\text { usage in a wide range of contexts" }\end{array}$ \\
\hline
\end{tabular}

Table 4: Scaling by changing behaviour

\begin{tabular}{|c|c|}
\hline $\begin{array}{l}\text { Uvin et al. } \\
(2000, \mathrm{pp} \text {. } \\
1411-1412)\end{array}$ & $\begin{array}{c}\text { "can occur through training, advocacy, knowledge creation, or advice. } \\
\text { The targets can be other civil society organizations }[\ldots] \text { state agencies, } \\
\text { from the central to the local level; and private for-profit businesses, } \\
\text { such as banks, multinational corporations, etc." }\end{array}$ \\
\hline $\begin{array}{c}\text { Earl et al. }(2001, \\
\text { p. } 1)\end{array}$ & $\begin{array}{l}\text { "Outcomes are }[\ldots] \text { changes in the behaviour, relationships, activities, } \\
\text { or actions of the people, groups, and organizations with whom a pro- } \\
\text { gram works }[\ldots . .] \text { aimed at contributing to specific aspects of human } \\
\text { and ecological well-being by providing partners with new tools, tech- } \\
\text { niques, and resources to contribute to the development process" } \\
\text { "Boundary partners are those individuals, groups, and organizations } \\
\text { with whom the program interacts directly and with whom the pro- } \\
\text { gram anticipates opportunities for influence" }\end{array}$ \\
\hline $\begin{array}{l}\text { Duggan et al. } \\
(2013, \text { p. } 159)\end{array}$ & $\begin{array}{l}\text { "involves other sectors/stakeholder groups in the process of expan- } \\
\text { sion-from the level of grassroots organizations to policymakers, } \\
\text { donors, development institutions and investors at international levels" }\end{array}$ \\
\hline $\begin{array}{l}\text { McLean and } \\
\text { Gargani }(2019 \text {, } \\
\text { p. 66) }\end{array}$ & $\begin{array}{l}\text { "coordinate the actions of diverse actors with multiple agendas and } \\
\text { perspectives in a way that balances private interests and the public } \\
\text { good." }\end{array}$ \\
\hline $\begin{array}{c}\text { Uvin et al. } \\
(2000, \text { p. } 1418)\end{array}$ & $\begin{array}{c}\text { creation "of strategic and programmatic knowledge that can be spun } \\
\text { off and/or integrated into the two mainstream sectors of society: gov- } \\
\text { ernments and markets" }\end{array}$ \\
\hline
\end{tabular}

\section{Table 5: Scaling by building sustainability}

\begin{tabular}{|c|c|}
\hline $\begin{array}{c}\text { Uvin et al. } \\
(2000, \text { p. } 1412)\end{array}$ & $\begin{array}{r}\text { "Enhancing organizational sustainability" through "movement from } \\
\text { the uncertainties of the entrepreneurial beginning [...] to the long- } \\
\text { term solidity of programmatic institutions." }\end{array}$ \\
\hline $\begin{array}{c}\text { Gundel et al. } \\
(2001 . \text { p. } 1)\end{array}$ & $\begin{array}{r}\text { "creating sustained poverty alleviation and increasing local capacity for } \\
\text { innovation" }\end{array}$ \\
\hline
\end{tabular}




\begin{tabular}{|c|c|}
\hline $\begin{array}{l}\text { Duggan et al. } \\
(2013, \text { p. } 159, \\
\text { drawing on } \\
\text { CGIAR (1999)) }\end{array}$ & $\begin{array}{l}\text { "increasing participation by decentralization of accountabilities and } \\
\text { responsibilities, particularly in breaking down big programmes into } \\
\text { smaller programmes/projects" }\end{array}$ \\
\hline $\begin{array}{l}\text { Wenger et al. } \\
(2002, \text { p. } 4)\end{array}$ & $\begin{array}{c}\text { "Communities of practice are groups of people who share a concern, } \\
\text { a set of problems, or a passion about a topic, and who deepen their } \\
\text { knowledge and expertise in this area by interacting on an ongoing } \\
\text { basis" }\end{array}$ \\
\hline $\begin{array}{c}\text { Uvin et al. } \\
\text { (2000, p. 1418) }\end{array}$ & $\begin{array}{l}\text { "Impact, finally, is not only about the number of beneficiaries or even } \\
\text { the specific policy changes won, but also about local capacity built, } \\
\text { intersectoral contacts developed, norms of trust and cooperation } \\
\text { strengthened, and democratic space and social diversity reinforced" }\end{array}$ \\
\hline $\begin{array}{l}\text { McLean and } \\
\text { Gargani }(2019 \\
\text { p. 63) }\end{array}$ & $\begin{array}{l}\text { "Optimal Scale is the point at which the magnitude, variety, sustain- } \\
\text { ability, and equity of impacts are balanced in a way that is endorsed." } \\
\text { (italics in original) }\end{array}$ \\
\hline
\end{tabular}

\section{Research findings that demonstrate the four scaling dimensions}

We now map research findings, from the studies listed above in Table 1, against the four scaling categories in the proposed taxonomy:

- scaling by expanding coverage

- scaling by broadening activities

- scaling by changing behaviour

- scaling by building sustainability

\section{Scaling by expanding coverage}

Taking innovations (commercial and social) to market

The notion of scaling by expanding coverage, when conceived narrowly, can refer simply to taking an innovation "to market" in a purely commercial sense. While the taxonomy proposed in this article actively seeks to avoid this kind of narrow focus, it cannot be denied that taking an innovation to market is indeed a marker of scaling. Research has found ample evidence of both product and process innovations being taken to market-via commercial enterprises or, even more often, social enterprises. For instance, the Oriakhogba (2020a, 2020b) case study of the Woza Moya craft collective in KwaZulu-Natal, South Africa, finds that the initiative had scaled from an original 15 Zulu women beadworkers to having more than 350 traditional crafters, almost all of them women, involved in several arts and crafts activities, including woodcarving, ceramics, sewing, basket-weaving, and beadwork. The study of maker collectives in South Africa's Gauteng Province (Kraemer-Mbula \& Armstrong, 2017) also finds evidence of innovations being taken to market, including the RepRap Morgan 3D printer and the Robohand 3D-printed prosthetic (Kraemer-Mbula \& Armstrong, 2017). Belete's (2018a, 2018b) study of footwear and textile MSEs operating in informal-sector clusters in the Ethiopian capital Ad- 
dis Ababa finds evidence that the enterprises were able to make use of the clusters to engage in rapid market commercialisation of new products, i.e., of new designs. Perhaps the most dramatic example of scaling through taking innovations to market that has been studied to date is the case of Nigeria's Nollywood film industry. As Oguamanam $(2018,2020)$ illuminates, participants in Nollywood have developed innovative business models-grounded in low-cost production, locally-attractive narratives, and low-cost distribution-which have managed to scale across Nigeria, across the African continent, into the African diaspora outside the continent, and internationally to non-African consumers.

\section{Prototyping innovations (commercial and social)}

For innovation-based enterprises, the first step on the path towards scaling through expansion of coverage is typically a prototyping stage. Some may argue that this stage is a "pre-scaling" phase and should not be regarded as scaling, but the taxonomy we propose regards prototyping as integral to the scaling continuum. In the ElHoussamy and Rizk $(2018,2020)$ study of maker communities in North Africa (Egypt, Tunisia, Morocco), it is found that several of the interviewees regard their maker communities' primary role as being that of supporting innovators at the prototyping phase of enterprise development. In the aforementioned study of maker communities in Gauteng Province, South Africa (Kraemer-Mbula \& Armstrong, 2017), a similar sentiment is identified-i.e., that maker communities should prioritise prototyping - among the majority of the maker community interviewees from the eight communities studied.

\section{Participating in ICT-enabled networks}

Research findings suggest that another important element of scaling for many innovative African enterprises is that which occurs via participation in ICTenabled networks. Research in Uganda by Dagne and Oguamanam (2018) sheds light on how ICT use supports knowledge-sharing and market decision-making by smallholder farmers. Baarbé et al. $(2017,2019)$ find enterprise-scaling being supported by farmers' and fishers' contributing to pools of "open data" through mobile apps and internet platforms, e.g., contribution to datasets on agricultural inputs, weather conditions, and market prices. Another instance of ICT network-enabled scaling is that of Nigeria's aforementioned Nollywood film industry (Oguamanam, 2018, 2020), with Nollywood's current distribution models strongly relying on ICT networks (complemented by offline physical networks).

\section{Participating in informal-sector clusters}

Scaling through expanded coverage can also be enabled by participation in informalsector clusters. The Jegede and Jegede (2018) study of Otigba computer village, an informal-sector cluster of ICT hardware enterprises in Lagos, finds that the cluster engenders a mix of both healthy competition and supportive, open cooperation among the enterprises. The enterprises participating in the cluster are able to expand 
their coverage through, among other things, access to new customers, new markets, and new suppliers of raw materials and inputs. The Belete (2018a, 2018b) study of two informal-sector clusters in the Ethiopian capital Addis Ababa-the Shiro Meda handloom-weaving cluster and the Merkato leather footwear manufacturing cluster-finds evidence of the enterprises increasing their market access through cluster participation. In Kumasi, Ghana, researchers Adu-Gyamfi and Adjei (2018) point to the remarkable scaling of Suame Magazine, the informal-sector metalworking and vehicle repair cluster, which has grown from roughly 50 artisans in the 1950s to a current estimate of approximately 200,000 people working in and around the cluster (Adu-Gyamfi \& Adjei, 2018, with citations of Obeng, 2001; Powell, 1981).

\section{Participating in formal-sector tech hubs}

Participation in formal-sector tech hubs is another means through which innovative African enterprises are able to expand coverage as a means to achieve scale. Nzomo et al. $(2020 \mathrm{a}, 2020 \mathrm{~b})$ look at the innovation dynamics of 25 Kenyan mobile tech startups, many of whom are interacting with tech hubs in Nairobi, and find that the enterprises' interactions with the hubs tend to generate increased coverage for the startups' innovations. The ElHoussamy et al. (2020) study of the views of leaders at three Egyptian tech hubs-Flat6Labs, AUC Venture Lab, and the Technology, Innovation and Entrepreneurship Center (TIEC) - finds that the hubs' hosted startups are able to expand coverage of their business models. The Abrahams (2020) study of innovation modalities at three South African tech hubs-Bandwidth Barn Khayelitsha and Workshop 17 in Cape Town, and Tshimologong Digital Innovation Precinct in Johannesburg-finds that startups' ability to scale through expanding coverage is generally enhanced by their participation in the hubs.

\section{Scaling by broadening activities}

\section{Engaging in product innovation}

The Belete (2018a, 2018b) study of handloom-weaving and leather footwear manufacturing enterprises in Addis Ababa's informal sector finds evidence that the enterprises in the two clusters studied are able to increase their capacity to develop new products (i.e., new designs). In their survey of the open collaborative innovation practices of 206 micro, small, and medium-sized enterprises (MSMEs) in Botswana, Ama and Okurut (2018) find that roughly half (51.3\%) of the enterprises say they have scaled their businesses through "new products and services developed" (2018, p. 28). 


\section{Engaging in process innovation}

In their study of the ICT hardware enterprises operating in the Otigba computer village in Lagos, Jegede and Jegede (2018) find process innovation to be central to the success of the enterprises: Oguamanam's $(2018,2020)$ study of the Nollywood film industry identifies clear instances of process innovations that have been successfully scaled by Nollywood entrepreneurs.

\section{Engaging in business-model innovation}

We regard "business models" as the models followed by social, commercial, or social-commercial hybrid enterprises in their efforts to achieve their objectives, balance their books, and/or turn a profit. The Armstrong et al. (2018) scan of South Africa's maker movement identifies several instances where maker communities are pursuing the broadening of activities through social-commercial hybrid business models. For example, the Kluyts MakerSpace in the town of Knysna, Western Cape Province, falls under a non-profit entity that is, in turn, linked to the for-profit Kluyts and Co. wood manufacturing (mostly furniture) factory, with both the makers and the factory working out of the same premises. Another study that reveals successful expansion in scope of activities through business-model innovation is Oguamanam's (2018, 2020) study of Nigeria's Nollywood film industry. Oguamanam explains how, when Nollywood started in the early 1990s, VHS cassette sellers, needing to find a way to sell excess stock, teamed up with creators of low-cost video dramas to produce content made available only on VHS $(2018,2020)$.

\section{Engaging in organisational-strategy innovation}

Innovations in organisational strategy are often made in support of scaling via expansion of the scope of activities. Indeed, the business-model examples outlined in the preceding sub-section all include elements of organisational strategy innovation. Another example emerges from the ElHoussamy and Rizk $(2018,2020)$ study of maker communities in North Africa. That study identifies organisational-strategy innovation in the work of Fab Lab Egypt, which "changed its role from being a makerspace that delivers workshops related to making, to more of a 'caretaker' role for other makerspaces in the country" (ElHoussamy \& Rizk, 2018, pp. 11, 32). Another example of organisational-strategy innovation is seen in the Kraemer-Mbula and Armstrong (2017) study of maker communities in South Africa's Gauteng Province. That study identifies significant organisational-strategy innovation in the work of the Geekulcha maker community, which has only a small core team but is able to deliver a multitude of digital skills programmes through its myriad partnerships with South African government departments (at national, provincial, and municipal levels), foreign donors, international organisations, and private-sector IT firms. 


\section{Scaling by changing behaviour}

The taxonomy's conceptualisation of behaviour change is drawn from the Earl et al. (2001) outcome mapping framework detailed above, which sees developmental outcomes as being a function of "changes in the behaviour" of "boundary partners" (2001, p. 1).

\section{Collaborating with outside stakeholders}

The Jegede and Jegede (2018) study of the Otigba computer village in Lagos finds clear evidence of the cluster's hardware enterprises engaging in external collaborations of mutual benefit with enterprises outside the cluster, customers, and trade and industry associations. The Adu-Gyamfi and Adjei (2018) study of the Suame Magazine cluster in Kumasi, Ghana, finds a long history of collaboration between enterprises in the cluster and the Technology Consultancy Centre (TCC) at Kumasi's Kwame Nkrumah University of Science and Technology (KNUST). The Rutert and Traynor (2019) study of social innovation and social entrepreneurship by two Indigenous enterprises in rural South Africa-Vukuzenzele Medicinal Plant Nursery and Garden (Vukuzenzele Plant Nursery) and the Kukula Traditional Health Practitioners Association (Kukula Healers) - finds that both enterprises had a strong ethos of collaboration, and behaviour change, in their interactions with external stakeholders.

\section{Engaging in systemised outreach and inclusion}

Another key modality for enterprises seeking scaling through behaviour change is their engagement in outreach and inclusion activities. Some of the most prominent examples of systemised outreach and inclusion efforts are found in the work of South African maker communities (Armstrong et al., 2018; De Beer et al., 2017; KraemerMbula \& Armstrong, 2017). The aforementioned Kluyts MakerSpace, in the South African town of Knysna, seeks to provide low-cost workspaces and enterprise opportunities to local woodworkers who have been marginalised by the decline in the region's once-vibrant furniture-making sector. Workspace, in the town of Hout Bay near Cape Town, has a skills-building project called The Employable Nation (TEN), which targets unemployed youth living in Hout Bay's impoverished informal settlements. The I Make Makers Lab in Irene, next to Pretoria, uses its mobile maker unit to work with under-employed artisans and craftspeople in rural areas. KATO's Women in Tech Cape Town and Geekulcha's Raeketsetsa are both projects that actively promote and build participation by girls and women in making. And the Wits University Tshimologong MakerSpace (formerly called the DIZ MakerSpace) in Johannesburg, the Gauteng Provincial Government eKasi Labs, and the Sebokeng FabLab all collaborate with innovators from low-income communities (De Beer et al., 2017). 


\section{Scaling by building sustainability}

The taxonomy's conception of scaling by building sustainability rests to a great extent on the assumption that the more sustainable an enterprise is, the greater its potential will be to engage in the taxonomy's other three kinds of scaling as covered in the preceding sub-sections.

\section{Participating in communities of practice}

ElHoussamy and Rizk $(2018,2020)$, in their study of the work of maker communities in North Africa, find that Fab Lab Egypt has developed a strong community of practice, as exemplified by its shift from delivery of services via a single makerspace to delivery of support to the entire network of Fab Labs in Egypt. ElHoussamy and Rizk also find that Alex Hackerspace in Alexandria is ensuring "close ties to the Egyptian maker community through co-hosting workshops and participating in events" (2018, p. 14), and that the majority of the makerspaces covered by the study are "engaged in activities that support upscaling and the ensuing sustainable knowledge-sharing processes" (2018, p. 32). In South African maker research, De Beer et al. (2017) find evidence of each individual maker collective taking steps to build a community of practice, as well as evidence of the makers building and participating in national, African continental, and international maker-oriented communities of practice-with ICT platforms allowing for community members to overcome barriers created by geographical remoteness.

\section{Developing human capital}

The Belete (2018a, 2018b) study of Ethiopian small enterprises finds in-house, onthe-job training to be integral to the enterprises' ability to scale up their operations. The Jegede and Jegede (2018) study of the Otigba ICT cluster in Lagos finds a link between informal MSEs' in-house training and annual turnover and, in turn, increased innovation capability. In their survey of Botswana small enterprises, Ama and Okurut (2018) find that $56.4 \%$ of the enterprises say they have scaled via an "increased number of skilled employees", and nearly half (48.7\%) say they had scaled "through motivation of their staff" (2018, p. 28).

\section{Engaging in open, collaborative innovation}

While research has found open, collaborative innovation to be relevant to all four of the taxonomy's scaling categories, its strongest roles are likely here in the fourth category: scaling by building sustainability. The Baarbé et al. $(2017,2019)$ study of sharing of open data to support scaling of small-scale farming and fishing enterprises finds strong evidence of open, collaborative approaches, particularly in the case of the Abalobi fishing management mobile apps in South Africa, developed collaboratively by project leaders and small-enterprise fishers. Open collaboration is also found to be central to the sustainable scaling of enterprises in three aforementioned informalsector clusters- the Otigba ICT hardware cluster in Lagos (Jegede \& Jegede, 2018), the Suame Magazine informal-sector cluster in Kumasi, Ghana (Adu-Gyamfi \& 
Adjei, 2018), and the Shiro Meda handloom-weaving cluster in Addis Ababa (Belete, 2018a, 2018b) — and in the Woza Moya craft enterprises project in KwaZulu-Natal, South Africa (Oriakhogba, 2020a, 2020b). Also, the studies of maker communities in South Africa, Egypt, Tunisia, and Morocco have found an ethos of open collaborative innovation to be a central motivation for individuals' participation in these communities, and thus a crucial driver of sustainability (see Armstrong et al., 2018; De Beer et al., 2017; ElHoussamy \& Rizk, 2018, 2020; Kraemer-Mbula \& Armstrong, 2017).

\section{Grounding innovations in socialchallenges and environmental management}

In their study of the use of 3D-printing by social entrepreneurs in South Africa and Kenya, Schonwetter and Van Wiele (2020) find that the entrepreneurs perceive scaling "as being linked to becoming (more) sustainable, and increasing the impact of their work and products" (2020, p. 18). In their case study of scaling of smallholder farming in Uganda, Dagne and Oguamanam (2018, p. 7) identify the importance of "paying attention to environmentally sustainable practices" as part of "scaling up agricultural economies". The Baarbé et al. research $(2017,2019)$ into the Abalobi mobile apps developed for and with South African fishers find environmental management goals to be interwoven with scaling goals. The two South African Indigenous enterprises studied by Rutert and Traynor (2019)—Vukuzenzele Plant Nursery and the Kukula Healers-are found to have forged strong links to livelihood development and responsible environmental stewardship in the impoverished, remote rural area where they are based.

\section{Establishing communal knowledge governance}

In their study of potential scaling of production and market access by Ugandan smallholder farmers,Dagne and Oguamanam (2018) find that one group of farmers, the vanilla growers of Uganda's Mukono District, could potentially increase the sustainability, through scaling, of their production and market share if they were to communally develop a geographical indication (GI), i.e., a trademark that promotes and protects the locally specific features of Mukono vanilla. In the Rutert and Traynor (2019) study, a key dimension of the Kukula Healers' success is found to lie in their development of a bio-cultural community protocol $(\mathrm{BCP})$ to govern the medicinal plant-related traditional knowledge (TK) held by the organisation's members.

\section{Conclusions}

In conclusion, it must once again be stressed that the four scaling conceptions in the taxonomy proposed in this article are conceived as overlapping, i.e., one can expect to find more than one, and often all, of these four scaling elements present in the actions and objectives of a knowledge-based enterprise operating in an African innovation setting. It is for that reason that several studies are referenced numerous times in this article's mapping of research findings against the taxonomy. 
In setting out these four overlapping conceptions of scaling, which we have found to be valuable for the mapping of research findings, it is our hope that we are providing a framework that can be useful to other researchers, and to policymakers, scholars, private-sector players, civil society actors and the actual African enterprises engaged in knowledge-based innovation in the continent's myriad and vibrant innovation settings.

\section{References}

Abate, G., Borzaga, C., \& Getnet, K. (2014). Cost-efficiency and outreach of microfinance institutions: Trade-offs and the role of ownership. Journal of International Development, 26(6), 923-932. https://doi.org/10.1002/jid.2981

Abrahams, L. (2020). Innovation entanglement at three South African tech hubs. The African Journal of Information and Communication (AJIC), 26, 1-29. https://doi.org/10.23962/10539/30358

Adu-Gyamfi, Y., \& Adjei, B. (2018). Skills development, knowledge and innovation at Suame Magazine, Kumasi. Open AIR Working Paper 16. https://openair.africa/skillsdevelopment-knowledge-and-innovation-at-suame-magazine-kumasi/

Agapitova, N., \& Linn, J. F. (2016). Scaling up social enterprise innovations: Approaches and lessons. Brookings Global Economy \& Development Working Paper 95.

Alvarez, S., Douthwaite, B., Thiele, G., Mackay, R., Cordoba, D., \& Tehelen, K. (2010). Participatory impact pathways analysis: A practical method for project planning and evaluation. Development in Practice, 20(8), 946-958. https://doi.org/10.1080/09614524.2010.513723

Ama, N. O., \& Okurut, F. N. (2018). MSMEs and open collaborative innovation in Botswana. Open AIR Working Paper 15.

Anane, G. K., Cobbinah, P. B., \& Manu, J. K. (2013). Sustainability of small and medium scale enterprises in rural Ghana: The role of microfinance institutions. Asian Economic and Financial Review, 3(8), 1003-1017.

Armstrong, C., De Beer, J., Kraemer-Mbula, E., \& Ellis, M. (2018). Institutionalisation and informal innovation in South African maker communities. Journal of Peer Production (JoPP), 12, 14-42. http://peerproduction.net/wp-content/ uploads/2018/07/jopp_issue12_vol1of3.pdf

Avenstrup, R., Liang, X., \& Nellemann, S. (2004). Kenya, Lesotho, Malawi and Uganda: Universal primary education and poverty reduction. World Bank.

Baarbé, J., Blom, M., \& De Beer, J. (2017). A data commons for food security. Open AIR Working Paper 2 \& IASC 2017 Conference Paper.

Baarbé, J., Blom, M., \& De Beer, J. (2019). A proposed "agricultural data commons" in support of food security. The African Journal of Information and Communication (AJIC), 23, 1-33. https://doi. org/10.23962/10539/27534

Barker, P., Reid, A., \& Schall, M. (2016). A framework for scaling up health interventions: Lessons from large-scale improvement initiatives in Africa. Implementation Science, 11, 1-11. https://doi.org/10.1186/s13012-016-0374-x 
Bayai, I., \& Ikhide, S., (2016). Life cycle theory and financial sustainability of selected SADC microfinance institutions (MFIs). The Journal of Developing Areas, 50(6), 121-132. https://doi.org/10.1353/jda.2016.0120

Belete, W. (2018a). Determinants of innovation in Ethiopian informal-sector micro and small enterprises (MSEs). Open AIR Working Paper 13.

Belete, W. (2018b). Patterns of innovation and knowledge in two Ethiopian informal- sector clusters: A study of the Shiro Meda handloom-weavers and Merkato shoemakers. The African Journal of Information and Communication (AJIC), 22, 83-109. https://doi. org/10.23962/10539/26170

Bocken, N. M. P., Fil, A., \& Prabhu, J. (2016). Scaling up social businesses in developing markets. Journal of Cleaner Production, 139, 295-308. https:// doi.org/10.1016/j.jclepro.2016.08.045

Bouwen, R., \& Taillieu, T. (2004). Multi-party collaboration as social learning for interdependence: Developing relational knowing for sustainable natural resource management. Journal of Community and Applied Social Psychology, 14(3), 137-153. https://doi.org/10.1002/ casp.777

Bradach, J., \& Grindle, A. (2014, February 19). Transformative scale: The future of growing what works. Stanford Social Innovation Review.

Burns, C. (2008). Scaling up microfinance in Africa: Best practices and a case study from Kenya. SPICE: Philosophy, Politics, E Economics Undergraduate Journal, Spring, 7-34.

Chopra, M., \& Ford, N. (2005). Scaling up health promotion interventions in the era of HIV/AIDS: Challenges for a rights based approach. Health Promotion International, 20(4), 383-390. https://doi.org/10.1093/heapro/dai018

Coe, R., Sinclair, F., \& Barrios, E. (2014). Scaling up agroforestry requires research 'in' rather than 'for' development. Current Opinion in Environmental Sustainability, 6(1), 73-77. https://doi.org/10.1016/j. cosust.2013.10.013

Coffman, J. (2010). Broadening the perspective on scale. The Evaluation Exchange, XV(I), 2-3.

Consultative Group on International Agricultural Research (CGIAR). (1999). Scale up! Highlights and synthesis of proceedings of the CGLAR NGO Committee Workshop on Scaling up Sustainable Agriculture Initiatives. The NGO Committee, Global Forum on Agricultural Research, CGIAR. World Bank.

Cooley, L., \& Kohl, R. (2006). Scaling up - from vision to large-scale change. Management Systems International.

Coviello, N. (2019). Is a high-growth firm the same as a 'scale-up'? Lazaridis Institute for the Management of Technology Enterprises, Wilfrid Laurier University, Waterloo, Canada.

Critchley, W. (1999). Harnessing traditional knowledge for better land husbandry in Kabale district, Uganda. Mountain Research and Development, 19(3), 261-272.

Dagne,T.W., \&Oguamanam,C.(2018). ICTs in agriculturalproduction and potential deployment in operationalising geographical indications in Uganda. https://openair.africa/ icts-in-agricultural-production-and-potential-deployment-in-operationalisinggeographical-indications-in-uganda/ 
De Beer, J., Armstrong, C., Ellis, M., \& Kraemer-Mbula, E. (2017). A scan of South Africa's maker movement. Open AIR Working Paper 9. https://openair.africa/a-scan-ofsouth-africas-maker-movement/

De Beer, J., Armstrong, C., Oguamanam, C., \& Schonwetter, T. (Eds.). (2014). Innovation and intellectual property: Collaborative dynamics in Africa. UCT Press.

DeJong, J., \& UNESCO (2014). Comprehensive sexuality education: The challenges and opportunities of scaling-up. https://unesdoc.unesco.org/ ark:/48223/pf0000227781

Domurath, A., \& Coviello, N. (2020, March 9). We must break down barriers that prevent companies from scaling up. The Globe and Mail.

Duggan, M. S., Smith, T. F., \& Thomsen, D. C. (2013). Scaling sustainability learning: Size and scope matter. Journal of Education for Sustainable Development, 7(2), 151-165. https://doi.org/10.1177/0973408214526484

Earl, S., Carden, F., \& Smutylo, T. (2001). Outcome mapping: Building learning and reflection into development programs. International Development Research Centre (IDRC).

Ebrahim, A., \& Rangan, V. K. (2014). What impact? A framework for measuring the scale and scope of social performance. California Management Review, 56(3), 118-141. https://doi.org/10.1525/cmr.2014.56.3.118

ElHoussamy, N., \& Rizk, N. (2018). The maker movement across North Africa. Open AIR Working Paper 17.

ElHoussamy, N., \& Rizk, N. (2020). Innovation practices at makerspaces in Egypt, Tunisia and Morocco. The African Journal of Information and Communication (AJIC), 26, 1-25. https://doi.org/10.23962/10539/30357

ElHoussamy, N., Weheba, N., \& Rizk, N. (2020). Power relations, innovation, scaling, and knowledge governance at three Egyptian tech hubs: An initial exploration. Open AIR Working Paper 21. https://openair.africa/power-relations-innovation-scaling-andknowledge-governance-at-three-egyptian-tech-hubs-an-initial- exploration/

Foster, C., \& Heeks, R. (2013). Innovation and scaling of ICT for the bottom-of-thepyramid. Journal of Information Technology, 28(4), 296-315.

https://doi.org/10.1057/jit.2013.19

Franzel, S., Cooper P., \& Denning, G. L. (2001). Scaling up the benefits of agroforestry research: Lessons learned and research challenges. Development in Practice, 11(4), 524-534. https://doi.org/10.1080/09614520120066792

Gillespie, S. (2004). Scaling up community-driven development: A synthesis of experience. FCND Discussion Paper No. 181. Food Consumption and Nutrition Division (FCND), International Food Policy Research Institute (IFPRI).

Gilson, G., \& Schneider, H. (2010). Managing scaling up: What are the key issues? Health Policy E Planning, 25(2), 97-98. https://doi.org/10.1093/ heapol/czp067

Gündel,S.,Hancock,J.,\&Anderson, S.(2001). Scaling-up strategies for research in natural resources management: A comparative review. Natural Resources Institute.

Huaynoca, S., Chandra-Mouli, V., Yaqub Jr,N.,\&Denno,D.(2014). Scaling up comprehensive sexuality education in Nigeria: From national policy to nationwide application. Sex Education, 14(2), 191-209. https://doi.org/10.1080/14681811.2013.856292

Igoe, J. (2003). Scaling up civil society: Donor money, NGOs and the pastoralist land rights movement in Tanzania. Development and Change, 34(5), 863-885.

https://doi.org/10.1111/j.1467-7660.2003.00332.x 
International Institute of Rural Reconstruction (IIRR). (2000). Going to scale: Can we bring more benefits to more people more quickly? http://www.fao.org/docs/eims/ upload/207909/gfar0086.pdf

Jegede, O. O., \& Jegede, O. E. (2018). Determinants of innovation capability in informal settings: The case of Nigeria's clustered ICT microenterprises. Open AIR Working Paper 12. https://openair.africa/determinants-of-innovation-capability-in-informal-settingsthe- case-of-nigeriais-clustered-ict-microenterprises/

Johns, B., \& Torres, T.T. (2005). Costs of scaling up health interventions: A systematic review. Health Policy and Planning, 20(1), 1-13. https://doi. org/10.1093/heapol/czi001

Koliba, C., \& Gadja, R. (2009). "Communities of practice” as an analytical construct: Implications for theory and practice.International Journal of Public Administration, 32, 97-135. https://doi.org/10.1080/01900690802385192

Korten, D. (1980). Community organization and rural development: A learning process approach. Public Administration Review, 40(5), 480-511.

https://doi.org/10.2307/3110204

Kraemer-Mbula, E., \& Armstrong, C. (2017). The maker movement in Gauteng Province, South Africa. Open AIR Working Paper 6. https://openair.africa/the-maker-movementin-gauteng-province-south-africa/

Lazaridis Institute. (2016). Scaling success: Tackling the management gap in Canada's technology sector. Lazaridis Institute for the Management of Technology Enterprises, Wilfrid Laurier University, Waterloo, Canada.

Mangham, L. J., \& Hanson, K. (2010). Scaling up in international health: What are the key issues? Health Policy and Planning, 25(2), 85-96.

https://doi.org/10.1093/heapol/czp066

McLean,R.,\&Gargani,J.(2019).Scaling impact:Innovation for the publicgood. International Development Research Centre (IDRC). https://doi.org/10.4324/9780429468025

Mokaddem, L. (2009). Concept note on microfinance scaling up in Africa: Challenges ahead and way forward. African Development Bank.

Myers, R. G. (1992). The twelve who survive: Strengthening programmes of early childhood development in the Third World. UNESCO/Routledge.

Noordin, Q. Niang, A., Jama, B., \& Nyasimi, L. (2001). Scaling up adoption and impact of agroforestry technologies: Experiences from western Kenya. Development in Practice, 11(4), 509- 523. https://doi.org/10.1080/09614520120066783

Nwuneli, N.O.(2016). Social innovation in Africa: A practical guide for scaling impact. Routledge. https://doi.org/10.4324/9781315646190

Nzomo, V., Mwangi, J., Matu-Mureithi, L., Muchiri, C .W., \& Rutenberg, I. (2020a). Modes of innovation and enterprise development by Nairobi's mobile tech startups. Open AIR Working Paper 22.

Nzomo, V., Mwangi, J., Matu-Mureithi, L., Muchiri, C. W., \& Rutenberg, I. (2020b). Drivers and modalities of collaborative innovation among Nairobi's mobile tech start-ups. The African Journal of Information and Communication (AJIC), 26, 1-24. https://doi.org/10.23962/10539/30359

Obeng, G. Y. (2001). Kumasi Suame Magazine: A background paper. UNU/INTECH-KITE Research Project, Kumasi, Ghana. 
Oguamanam, C. (2018). The Nollywood phenomenon: Innovation, openness and technical opportunism in the modeling of successful African entrepreneurship. Open AIR Working Paper 19.

Oguamanam, C. (2020). The Nollywood phenomenon: Innovation, openness, and technological opportunism in the modeling of successful African entrepreneurship. The Journal of World Intellectual Property, 23, 518-545.

https://doi.org/10.1111/jwip.12162

Open African Innovation Research (Open AIR). (n.d.). https://openair.africa

Open AIR. (2020). Scaling innovation: How open collaborative models help scale Africa's knowledge-based enterprises. https://openair.africa/scaling-innovation-how-opencollaborative-models-help-scale-africas-knowledge-based-enterprises/

Organisation for Economic Co-operation and Development (OECD). (2018). Enabling SMEs to scale up. Discussion Paper, SME Ministerial Conference, Mexico City, 22-23 February.

Oriakhogba, D. O. (2020a). Empowering rural women crafters in KwaZulu-Natal: The dynamics of intellectual property, traditional cultural expressions, innovation and social entrepreneurship. South African Law Journal, 37(1), 145-172.

Oriakhogba, D. O. (2020b). Working around the gender gap in intellectual property regimes: Empowerment of women beadworkers through open, inclusive innovation and social entrepreneurship in KwaZulu-Natal, South Africa. Open AIR Working Paper 23.

Powell, J. (1981). Strategy for the development of informal industries in Ghana. Journal of Environmental Planning and Management, 23(1), 33-36.

https://doi.org/10.1080/00320718108711603

Powell, J. (1990). Evolution in engineering-the survival of the fitter. Small Enterprise Development, 1(2), 48-51. https://doi.org/10.3362/0957-1329.1990.020

Reilly, K. M. A., \& Smith, M. L. (2013). The emergence of open development in a network society. In M. L. Smith, \& K. M. A. Reilly (Eds.), Open development: Networked innovations in international development (pp. 15-50). MIT Press.

Republic of Kenya (2012). Micro and Small Enterprises Act, No. 55 of 2012.

Rutert, B., \& Traynor, C. (2019). Complexities of social innovation and social entrepreneurship by two Indigenous organisations in rural South Africa. Open AIR Working Paper 20. https://openair.africa/complexities-of-social-innovation-and-socialentrepreneurship-by-two-indigenous-organisations-in-rural-south-africa/

Scarborough, V., Killough, S., Johnson, D. A., \& Farrington, J. (Eds.). (1997). Farmer-led extension: Concepts and practices. Intermediate Technology.

https://doi.org/10.3362/9781780444949

Schonwetter, T., \& Van Wiele, B. (2018). 3D printing: Enabler of social entrepreneurship in Africa? The roles of FabLabs and low-cost 3D printers. Open AIR Working Paper 18.

Schonwetter, T., \& Van Wiele, B. (2020). Social entrepreneurs' use of fab labs and 3D printing in South Africa and Kenya. The African Journal of Information and Communication (AJIC), 26, 1-24. https://doi.org/10.23962/10539/30356

Simmons, R., Fajans, P., \& Ghiron, L. (2007). Introduction. In R. Simmons, P. Fajans, \& L. Ghiron (Eds.), Scaling up health service delivery: From pilot innovations to policies and programmes (pp.vii-xvii). WHO and ExpandNET. 
Simmons, E., \& Shiffman, J. (2007). Scaling up health service innovations: A framework for action. In R. Simmons, P. Fajans, \& L. Ghiron (Eds.), Scaling up health service delivery: From pilot innovations to policies and programmes (pp. 1-30). WHO and ExpandNET.

South African Department of Small Business Development. (2019). Revised Schedule 1 of the National Definition of Small Enterprise in South Africa.

Spicer, N., Bhattacharya, D., Dimka, R., Fanta, F., Mangham-Jefferies, L., Schellenberg, J. . .Wickremasinghe, D. (2014). 'Scaling-up is a craft not a science': Catalysing scaleup of health innovations in Ethiopia, India and Nigeria. Social Science E Medicine, 121(November), 30-38. https://doi.org/10.1016/j.socscimed.2014.09.046

Subramanian, S., Naimoli, J., Matsubayashi, T., \& Peters, D. H. (2011). Do we have the right models for scaling up health services to achieve the Millennium Development Goals? BMC Health Services Research, 11, 1-10.

https://doi. org/10.1186/1472-6963-11-336

US Agency for International Development (USAID). (2015). Scaling up interventions to prevent and respond to gender-based violence: An analytical report.

Uvin, P. (1995). Fighting hunger at the grassroots: Paths to scaling up. World Development, 23(6), 927-939. https://doi.org/10.1016/0305-750X(95)00028-B

Uvin, P., \& Miller, D. (1996). Paths to scaling up: Alternative strategies for local nongovernmental organizations. Human Organization, 55(3), 344-354.

https://doi.org/10.17730/ humo.55.3.v44334362401041t

Uvin, P., Jain, P. S., \& Brown, L. D. (2000). Think large and act small: Toward a new paradigm for NGO scaling up. World Development, 28(8), 1409- 1419.

https://doi.org/10.1016/S0305-750X(00)00037-1

Wambugu, C., Franzel, S., Tuwei, P., \& Karanja, G. (2001). Scaling up the use of fodder shrubs in central Kenya. Development in Practice, 11(4), 487-494. https://doi.org/10.1080/09614520120066765

Wenger, E. (1998). Communities of practice: Learning, meaning and identity. Cambridge University Press. https://doi.org/10.1017/ CBO9780511803932

Wenger, E., McDermott, R. A., \& Snyder, W. (2002). Cultivating communities of practice: A guide to managing knowledge. Harvard Business Press.

Wigboldus, S., Klerkx, L., Leeuwis, C., Schut, M., Muilerman, S., \& Jochemsen, H. (2016). Systemic perspectives on scaling agricultural innovations. A review. Agronomy for Sustainable Development, 36(46), 1-20. https://doi.org/10.1007/s13593-016-0380-z

World Health Organisation (WHO), \& ExpandNet (2010). Nine steps for developing a scaling up strategy.

Yamey, G. (2011). Scaling global health interventions: A proposed framework for success. PloS Medicine, 8(6), 1-5. https://doi.org/10.1371/ journal.pmed.1001049

Yimga, J. (2018). Microfinance expansion and its effects on cost efficiency. The Quarterly Review of Economics and Finance, 69(August), 205-216.

https://doi.org/10.1016/j.qref.2018.03.006 